\title{
A new species of the genus Adelphinus Fairmaire et Coquerel, 1866 (Coleoptera: Tenebrionidae) from Iran
}

\section{Новый вид рода Adelphinus Fairmaire et Coquerel, 1866 (Coleoptera: Tenebrionidae) из Ирана}

\author{
M.V. Nabozhenko \\ M.В. Набоженко \\ Institute of Arid Zones, Russian Academy of Sciences, Chekhov str., 41, Rostov-on-Don 344006 Russia. E-mail: nalassus@mail.ru \\ Институт аридных зон ЮНЦ РАН, пр. Чехова, 41, Ростов-на-Аону 344006 Россия
}

Key words: Coleoptera, Tenebrionidae, Helopini, Adelphinus, new species, Iran.

Ключевые слова: Coleoptera, Tenebrionidae, Helopini, Adelphinus, новый виА, Иран.

Abstract. A new species Adelphinus (Adelphinops) dmitrii sp. n. is described from Iran (Fars Province). The species differs from close A. ordubadensis Reitter, 1890 (it is distributed in Armenia, Azerbaijan and Georgia) and A. afghanicus Kaszab, 1960 (it is distributed in Afghanistan) in the black body, two transverse depression near basal bead of pronotum, elytral interstriae with sparse granules, process of abdominal ventrite 1 between metacoxae with deep transverse depression. Key to species of the subgenus Adelphinops Reitter, 1922 is given.

Резюме. Описан новый виА Adelphinus (Adelphinops) dmitrii sp. n. из Ирана (провинция Фарс). Этот вид отличается от близких A. ordubadensis Reitter, 1890 (распространен в Армении, Азербайджане и Грузии) и A. afghanicus Kaszab, 1960 (распространен в Афганистане) черным телом, Авумя поперечными вАавлениями возме базального окаймкения переднеспинки, наличием мелких зернышек на межАурядьях надкрылий, сильным поперечным вАавлением отростка 1-го абдоминального вентрита между задними тазиками. Аана определительная таблица видов подрода Adelphinops Reitter, 1922

Adelphinus Fairmaire et Coquerel, 1866 is a small Western Palaearctic genus with species distributed in northern Africa, Transcaucasia and Afghanistan. Species of the genus Adelphinus are the flying moderate in size beetles $(8-12 \mathrm{~mm})$, which inhabit deserts and subdeserts. The genus belongs to the subtribe Helopina of the tribe Helopini and includes 2 subgenera [Reitter, 1922]. Three species of nominotypical subgenus are known from Northern Africa (Tunis, Algeria, Morocco), two species of the subgenus Adelphinops Reitter, 1922 have small ranges in Transcaucasia and Afghanistan [Reitter, 1890, 1922; Kaszab, 1960; Nabozhenko, Löbl, 2008; Abdurakhmanov, Nabozhenko, 2011]. The first species A. (Adelphinops) ordubadensis Reitter, 1890 is distributed in Armenia (Yerevan, Jrvezh District, Kotayk Province) [Kalashyan, 2010] and Azerbaijan (Mingechevir; Nakhichevan Autonomous Republic: Ordubad) and Georgia (Eldari) [Dzhambazishvili, 2000]. The second species, A. (Adelphinops) afghanicus Kaszab, 1960 is known only from the holotype from Afghanistan (labels of the holotype "J. Klapperich, Darufulun b. Kabul, 1800 m, 11.6.53, Afghanistan" and "Holotypus, 1960, +, Adelphinus afghanicus Kaszab") [Kaszab, 1960]. Species of this subgenus differ from nominotypical African species in the short, scarsely extending beyond pronotum antennae, not thickened scapus, monochrome elytra with rasp-shaped interstria. Species of Adelphinus were unknown from Iran, although the record of Adelphinus ordubadensis distributed in border regions of Azerbaijan is quite possible. A new species of the subgenus Adelphinops from southwestern Iran (Fars Province) is described below. This record greatly widened the range of the genus.

\section{Adelphinus (Adelphinops) dmitrii sp. n.} (Figs 1-5)

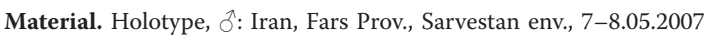
(leg. A. Klimenko). Holotype will be deposited in Zoological Institute of Russian Academy of Sciences (St. Petersburg, Russia).

Description. Male. Body slender, black, antennae and tarsi dark brown. Anterior margin of frontoclypeus almost straight, with projected angles. Head widest at eye level. Eyes moderately convex, widely separated. Head width 1.45 times wide of interocular spase. Genae strongly regularly rounded. Lateral margin of head with obtuse emargination between genae and frontoclypeus. Frontoclypeus strongly depressed, genae slightly elevated. Punctation of head coarse and dense, punctures round, often merged. Gula acute triangular, almost reaching anterior margin of vertex. Mentum longitudinal, with very weak middle ridge. Vertex rugosity punctated. Antennae short, with only 2 apical antennomeres extending beyond base of pronotum. Antennomeres shortened from $2^{\text {nd }}$ to $11^{\text {th}}$; antennomeres $8-11$ flattened; antennomere 10 with subequal length and width; antennomere 111.37 times as long as wide.

Pronotum transverse (1.5 times as wide as long), rectangular shape, widest little before middle, 1.3 times as wide as head. Lateral margins weakly rounded, anterior margin weakly widely emarginated, base weakly rounded. Angles widely rounded, anterior angles right, posterior angles weakly obtuse. Lateral margins and base distinctly beaded, anterior margin not beaded in middle. Disc of pronotum regularly weakly convex, with very narrowly flattened lateral sides and 2 transverse depression near basal bead. Punctation coarse and dense, as on head. Prothoracic hypomera narrowly flattened on outer margins, with dense rugose punctation. Prosternal process not convex. 


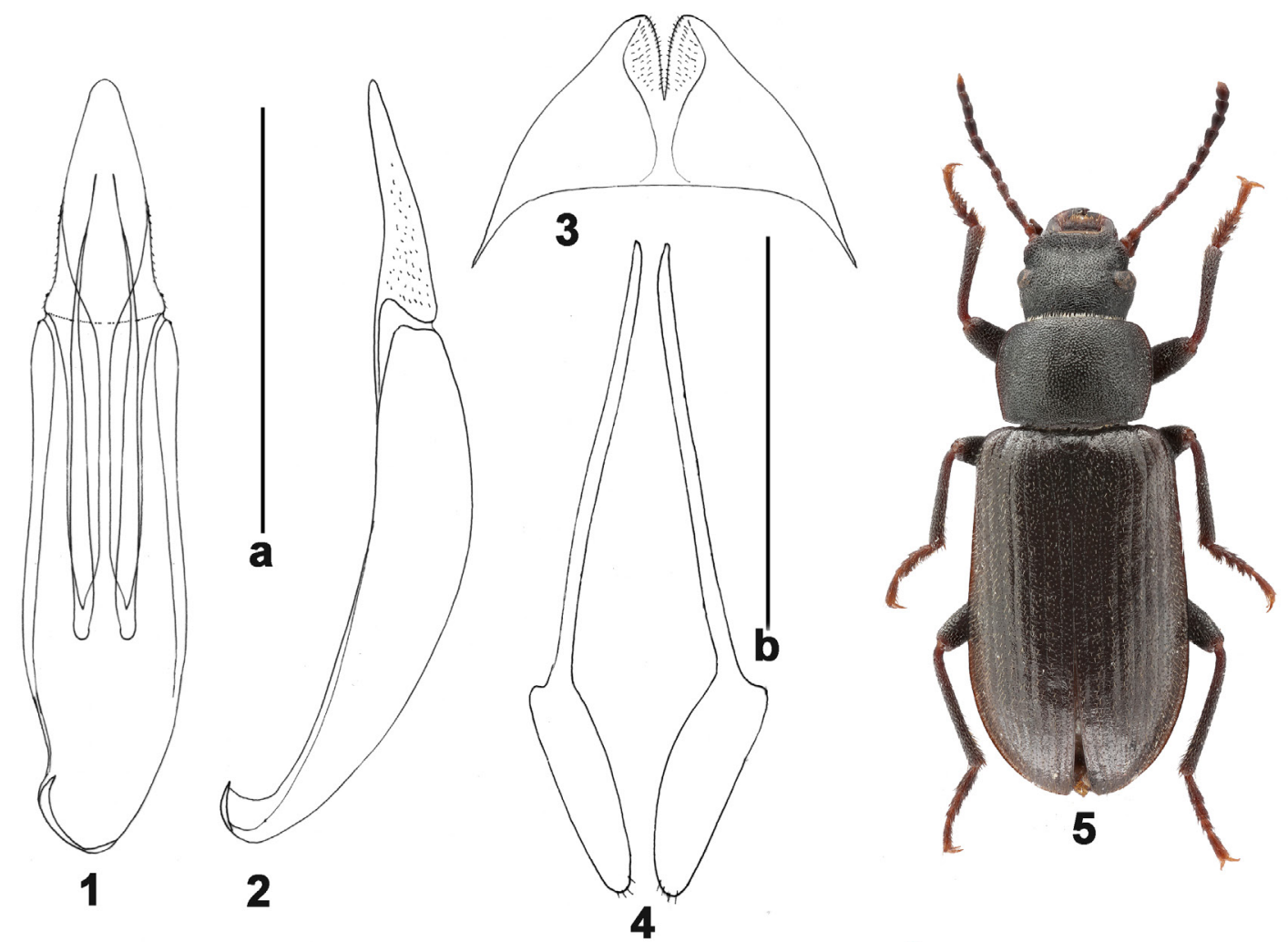

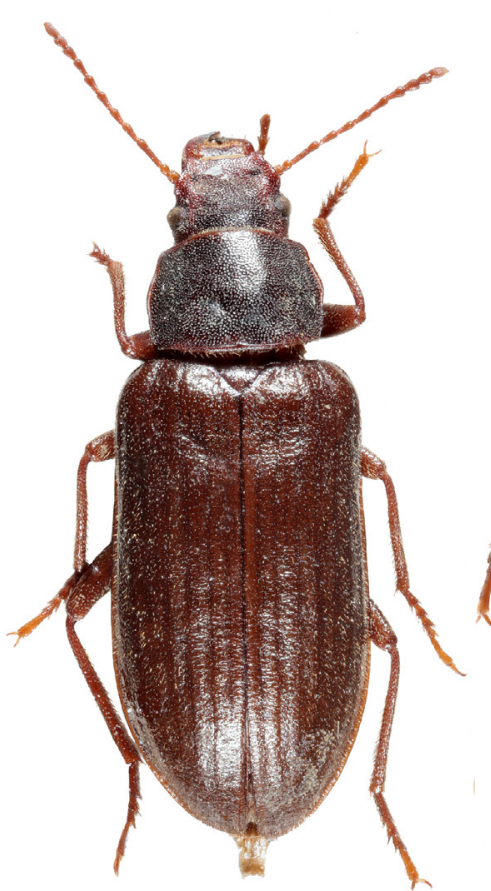

6

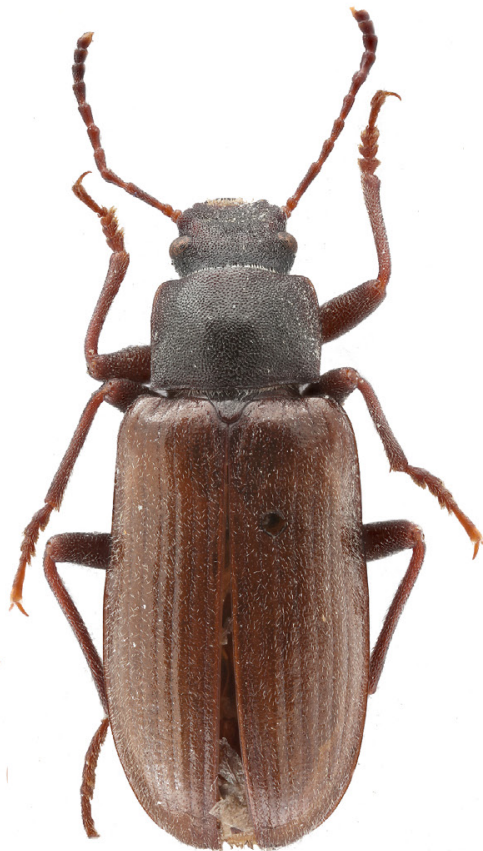

7

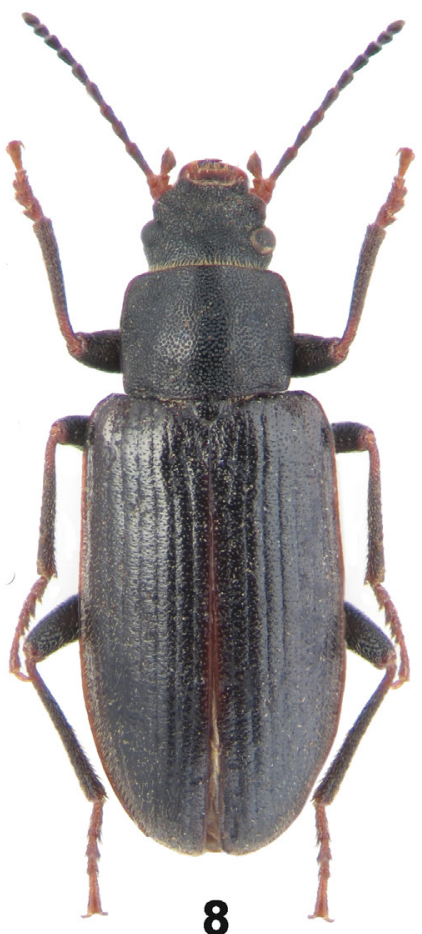

8

Figs 1-7. Species of the subgenus Adelphinops of the genus Adelphinus.

1-5 - A. dmitrii sp. n., holotype; 6 - A. afghanicus, holotype; 7 - A. ordubadensis (bicolour form, Eldari, Georgia); 8 - A. ordubadensis (monochrome form, Armenia, Goravan sands; photograph by K. Makarov and G. Karagyan from Kalashayn [2010]). 1 - aedeagus ventrally; 2 - aedeagus laterally; 3 - male inner sternite VIII; 4 - male gastral spicula. Scale bars 1 mm (a - for Figs 1, 2; b - for Figs 3, 4).

Рис. 1-7. Виды подрода Adelphinops рода Adelphinus.

1-5 - A. dmitrii sp. n., голотип; 6 - A. afghanicus, голотип; 7 - A. ordubadensis (Авухцветная форма, Эльдари, Грузия); 8 - A. ordubadensis (одноцветная форма, Армения, Гораванские пески; фотография К. Макарова и Г. Карагяна из Каlashayn [2010]). 1 - эдеагус вентрально; 2 -

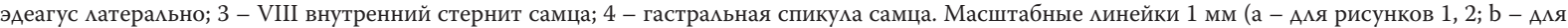
рисунков 3,4$)$. 
Elytra almost parallel, elongate (1.6 times as long as wide), widest after middle, 1.8 times as wide as head, 1.4 times as wide and 3.3 times as long as pronotum. Strial punctures connected in very fine but distinct furrows. Interstriae weakly convex, with small sparse granules, regularly covered with suberected short hairs. Epipleura slightly depressed, with fine sparse punctation and wrinkles, almost reaching sutural angles of elytra, ending before the apex. Epipleural carina completely visible dorsally.

Ventral side (excluding epipleura) completely covered with short recumbent pubescense. Metaventrite and metepisterna with fine and sparse rasp-shaped punctation. Abdominal ventrites with very fine dense puncation, ventrite 5 not beaded apically; process of abdominal ventrite 1 between metacoxae with deep transverse depression.

Trochanters with several moderately long hairs and one longer sensillum. Tibiae straight, with subrecumbent hairs on inner side. Pro- and mesotarsi widened, protarsomeres 2 and 3 transverse, mesotarsomeres longitudinal.

Body length $8.5 \mathrm{~mm}$, width $3.3 \mathrm{~mm}$.

Female unknown.

Differential diagnosis. Differences from two other species of the subgenus Adelphinops are given in the key.

Etymology. The species is named in memory of Dmitriy Matishov (5.09.1966-20.08.2015), the head of Institute of Aride Zones of Southern Scientific Centre RAS (Rostov-on-Don, Russia).

\section{Key to species of the subgenus Adelphinops of the genus Adelphinus}

1(2). Body black. Pronotum with two transverse depression near basal bead. Elytral interstriae with sparse granules. Process of abdominal ventrite 1 between metacoxae with deep transverse depression

A. dmitrii sp. n. (Figs 1-5)

2(1). Body brown, monochrome, or with light elytra and dark pronotum and head. Pronotum without transverse depressions near basal bead. Elytral interstriae with sparse rasp shaped punctures. Process of abdominal ventrite 1 between metacoxae with not deep round depression.

3(4). Body monochrome, brown. Strial punctures very little, almost invisible, elongate, not merged in furrows A. afghanicus (Fig. 6)
4(3). Body bicolour, with light brown elytra and dark brown pronotum and head or monochrom dark brown. Strial punctures little but distinct visible, round, merged in fine furrows A. ordubadensis (Figs 7, 8)

\section{Acknowledgements}

The author is much obliged to Ottó Merkl (Hungarian Natural History Museum, Budapest, Hungary) for provided the holotype of Adelphinus afghanicus, to Mark Kalashian (Scientific Centre of Zoology and Hydroecology of the National Academy of Sciences of Armenia) for provided the photograph of Adelphinus ordubadensis from Armenia and to Denis Kasatkin (Rostov Branch of All-Russian Center for Plant Quarantine, Rostov-on-Don, Russia) for preparation of other photographs.

The study was supported by the Russian Foundation for Basic Research 15-55-05099.

\section{References}

Abdurakhmanov G.M., Nabozhenko M.V. 2011. Keys and catalogue to darkling beetles (Coleoptera: Tenebrionidae s. str.) of the Caucasus and south of European part of Russia. Moscow: KMK Scientific Press Ltd. 361 p. (in Russian).

Dzhambazishvili M.Ya. 2000. Catalogue of darkling beetles (Coleoptera, Tenebrionidae) of Georgia. Trudy Instituta Zoologii. 20: 185-193 (in Russian).

Kalashyan M. 2010. Adelphinus ordubadensis Reitter, 1890. In: The Red Book of Animals of the Republic of Armenia: Invertebrates and Vertebrates. Yerevan: Zangak-97: 101.

Kaszab Z. 1960. Die Tenebrioniden Afghanistans, auf Grund der Ergebnisse der Sammelreise des Herrn J. Klapperich in den Jahren 1952/53 (Col.). 1. Fortsetzung und Schluss. Entomologische Arbeiten aus dem Museum G. Frey. 11: 1-179.

Nabozhenko M.V., Löbl I. 2008. Tribe Helopini. In: Catalogue of Palaearctic Coleoptera. Vol. 5. Tenebrionoidea. (I. Löbl, A. Smetana eds). Stenstrup: Apollo books: 241-257.

Reitter E. 1890. Neue Coleopteren aus Europa, den angrenzenden Ländern und Sibirien, mit Bemerkungen über bekannte Arten. Neuenter Theil. Deutsche Entomologische Zeitschrift. 1890: 145-164.

Reitter E. 1922. Bestimmungstabelle der palaearktischen Helopinae (Col. Tenebrionidae). Wiener Entomologische Zeitung. 39: 1-44, 113-171. 